\title{
Evaluation of Physicochemical Properties and Antioxidant Activity of Wheat-Red Kidney Bean Biscuits
}

\author{
Mukta Roy ${ }^{1}$, Sheikh Mohammad Nasirul Haque ${ }^{1}$, Rana Das ${ }^{2 *}$, Manobendro Sarker ${ }^{3}$, \\ Md. Azmain Al Faik², Shagor Sarkar4
}

\footnotetext{
${ }^{1}$ Department of Food Engineering and Tea Technology, Shahjalal University of Science and Technology, Sylhet, Bangladesh

${ }^{2}$ Department of Food Engineering and Technology, State University of Bangladesh, Dhaka, Bangladesh

${ }^{3}$ Department of Biomass Energy Engineering, Shanghai Jiao Tong University, Shanghai, China

${ }^{4}$ Department of Biosystems Engineering, Gyeongsang National University, Jinju, Republic of Korea

Email: *ranasust8@gmail.com
}

How to cite this paper: Roy, M., Haque, S.M.N., Das, R., Sarker, M., Al Faik, M.A. and Sarkar, S. (2020) Evaluation of Physicochemical Properties and Antioxidant Activity of Wheat-Red Kidney Bean Biscuits. World Journal of Engineering and Technology, 8, 689-699.

https://doi.org/10.4236/wjet.2020.84049

Received: September 5, 2020

Accepted: November 6, 2020

Published: November 9, 2020

Copyright $\odot 2020$ by author(s) and Scientific Research Publishing Inc. This work is licensed under the Creative Commons Attribution International License (CC BY 4.0).

http://creativecommons.org/licenses/by/4.0/

\begin{abstract}
This research was aimed to study the physicochemical properties and antioxidant activity of biscuits fortified with red kidney bean (Phaseolus vulgaris) powder. Proximate compositions, total phenol content, antioxidant activity, and functional properties of red kidney bean (RKB) powder were studied before and after the incorporation of red kidney bean in the biscuits. The bean powder was mixed with wheat flour at a level of $0 \%$ as control, $10 \%, 20 \%$, and $30 \%$ during dough preparation. Results revealed that RKB powder is a rich source of protein $(26.25 \%)$ together with carbohydrate $(59.7 \%)$, fat $(2.4 \%)$, and ash (3.27\%). The total phenolic content of bean powder was $14.15 \mathrm{mg}$ GAE/g. Kidney bean powder showed good functional properties including water absorption capacity (149.7\%), oil holding capacity (99.54\%), swelling capacity (4.6\%), and bulk density of $0.74 \mathrm{~g} / \mathrm{ml}$. After increasing the percentage of RKB with control, there were significant increases $(\mathrm{p}<0.05)$ in the levels of protein, moisture, ash, fat, while carbohydrate content and total gross energy decreased significantly. Investigation of total phenolic content showed the increasing trend with the higher RKB fortification, which amounted to $10.31 \mathrm{mg} \mathrm{GAE} / \mathrm{g}$ for control and $12.50 \mathrm{mg} \mathrm{GAE} / \mathrm{g}$ for 30\% RKB. DPPH radical scavenging activity was investigated for all the samples at five different concentrations. As there was an increase in the percentage of RKB and concentration of the samples, the antioxidant activity also increased significantly ( $\mathrm{p}<0.05$ ), where IC50 value decreased from $0.0228 \mathrm{mg} / \mathrm{ml}$ for control to $0.0289 \mathrm{mg} / \mathrm{ml}$ for $10 \% \mathrm{RKB}$, followed by $20 \%$ and $30 \% \mathrm{RKB}$, respectively. In sensory test, the control cake secured the highest score in color, flavor, tex-
\end{abstract}


ture and overall acceptability followed by the cake incorporated with $10 \%$ freeze-dried mushroom powder.

\section{Keywords}

Red Kidney Bean, Biscuit, Physicochemical, Phenol, Antioxidant Activity

\section{Introduction}

A large number of people in developing countries suffer from malnutrition. Food crisis and insecure food supply are two major causes of nutrition insufficiency. The countryside area of Bangladesh is suffering more due to the lack of knowledge as well as the scarcity of balanced diet, proper consumption of protein, vitamin, or mineral-rich foods. The high price of animal protein like meat, fish, milk, egg, etc. is another reason for malnutrition. Therefore, it is necessary to find alternative sources of animal protein. In this context, the legume is a good source of protein and one of the largely grown crops in Bangladesh. Many legumes, like lentil, chickpea, black gram, mung bean, groundnut, and kidney bean occupy about $5 \%$ of cropped area of Bangladesh and play an important role in rain-fed agriculture [1].

Legumes contain some micronutrients, such as iron, zinc, vitamin $\mathrm{A}$, and $\mathrm{E}$ [2]. Kidney bean (Phaseolus vulgaris) is one of the neglected legumes in Bangladesh. Kidney bean is one kind of herbaceous annual plant, grown for its edible dry seed. Kidney beans are also rich in phenolic content that possess different levels of antioxidant activity [3]. They are very important for food preservation as well as the defense of living systems against oxidative stress [4]. These health benefits, like curing cancer, heart disease, Alzheimer's, have been partially attributed to the presence of antioxidants in kidney bean, especially polyphenols [5]. Hence, the consumption of kidney beans is beneficial in keeping good health.

Kidney bean powder can be incorporated in biscuits and it is one of the cheap food items for low-income peoples in Bangladesh. The fortification of biscuits with red kidney bean (RKB) powder can enrich the protein and ash content as well as other beneficial bioactive compounds. The present study was undertaken to incorporate dark RKB powder in biscuits to enrich protein content and antioxidant activity. The further assessment was carried out to analyze the physicochemical and sensory properties value-added biscuits concerning RKB powder.

\section{Materials and Methods}

\subsection{RKB Collection and Powder Preparation}

Dark RKB was collected from the Bandar Bazar market of Sylhet, Bangladesh. At first, insect or physically damaged beans were removed visually. Sorted beans were treated by the sun-drying process to lower the moisture content. Then the dried beans were grounded from a local grinder house. The RKB powder was 
sieved and kept in an airtight container for further analyzing process.

\subsection{Preparation of Biscuits}

RKB powder was firstly mixed with market wheat flour at various level of $0 \%$ (control), 10\%, 20\%, and 30\%. Then $60 \mathrm{~g}$ paste made from the mixture of $504 \mathrm{~g}$ of powdered sugar, $30 \mathrm{~g}$ of milk powder, $252 \mathrm{~g}$ refined oil and $12 \mathrm{~g}$ of sodium bi-carbonate was added to mixed flour. $34 \mathrm{ml}$ of distilled water was also put into each mixture. Thereafter, the mixture was rubbed well to mix properly and avoid ball formation. The dough was given a shape of biscuit by hand with a thickness of $3.5 \mathrm{~mm}$, and baked in oven at $160^{\circ} \mathrm{C}$ for $20 \mathrm{~min}$. Then the biscuits were cooled for $30 \mathrm{~min}$ and packed in airtight food grade plastic bags for further analysis.

\subsection{Physicochemical and Functional Properties Analysis}

Chemical composition and functional properties of RKB and proximate compositions of biscuits after the incorporation of bean powder were analyzed. Protein content was measured according to the Official methods of Analysis [6], where factor 6.25 was used for the conversion of nitrogen to protein. The method described by [7] was used for the determination of fat content. Moisture and ash content were determined using Approved Methods of the American Association of Cereal Chemists [8]. Difference method by [9] was used to determine the total carbohydrate content. Energy value was calculated by multiplying carbohydrate, protein, and fat by their factorial values as follows:

$$
\begin{aligned}
& \text { Energy value }(\mathrm{kcal} / 100 \mathrm{~g}) \\
& =[(\text { carbohydrate } \% \times 4)+(\text { protein } \% \times 4)+(\text { crude fat } \% \times 9)]
\end{aligned}
$$

Swelling capacity was determined according to the method described by [10] with some modifications. Water absorption capacity and oil holding capacity were measured using the modified method reported by [11]. And bulk density was determined following the method of [12].

\subsection{Total Polyphenol Content (TPC)}

Folin-Ciocalteu method [13] was followed to determine total phenolic contents using UV visible spectrophotometer. $1.0 \mathrm{~mL}$ aliquot sample was mixed to $1.5 \mathrm{~mL}$ of deionized water and $0.5 \mathrm{~mL}$ of $0.1 \mathrm{M}$ Folin-Ciocalteu reagent, and were mixed methodically. After $1 \mathrm{~min}, 1.0 \mathrm{~mL}$ of $20 \%$ sodium carbonate solution was added and the mixture was again stirred thoroughly. The control for spectrometry analysis contained all chemical reagents excluding the sample. The sample was kept in incubation at $37^{\circ} \mathrm{C}$ for $30 \mathrm{~min}$ and the absorbance was taken at 750 $\mathrm{nm}$. The amount of phenolic contents in the sample was calculated using the standard calibration curve derived from known concentrations of gallic acid and the total phenolics were estimated as gallic acid equivalent (GAE).

Calculation of total polyphenol content:

$$
y=0.692 x+0.344
$$


where, $y=$ absorbance found by the sample tested and; $x=$ concentration found from the standard curve.

\subsection{DPPH Radical Scavenging Activity}

Antioxidant activity of bean powder and biscuit samples were measured at five different concentrations $(0.016 \mathrm{mg} / \mathrm{mL}, 0.08 \mathrm{mg} / \mathrm{mL}, 0.4 \mathrm{mg} / \mathrm{mL}, 2 \mathrm{mg} / \mathrm{mL}$ and $10 \mathrm{mg} / \mathrm{mL}$ ).

Our study followed the method described by [14] to assess the DPPH scavenging effects of samples. Briefy, $2.0 \mathrm{~mL}$ aliquot of the test sample (in methanol) and $2.0 \mathrm{~mL}$ of $0.16 \mathrm{mM}$ DPPH methanolic solution were mixed and vortexed for $1 \mathrm{~min}$, and then left to stay at room temperature for $30 \mathrm{~min}$ in the dark. The absorbance was taken at $517 \mathrm{~nm}$. The ability to scavenge the DPPH radical was calculated using the following equation:

Scavenging effect $(\%)=[1-($ A sample - A sample blank/A control $)] \times 100$ where, A control is the absorbance of the control (DPPH solution without sample); A sample is the absorbance of the test sample (DPPH solution plus test sample) and A sample blank is an absorbance of the sample only (sample without DPPH solution). Ascorbic acid was used as positive control.

\subsection{Statistical Analysis}

All the data were presented in this study as mean value with standard deviation (SD). A significant difference among samples was measured using Analysis of variance $(p<0.05)$. To analyze the data SPSS-17 statistical software (SPSS Inc., Chicago, IL, USA) was used.

\section{Results and Discussion}

\subsection{Composition of RKB Powder}

The nutritional composition of RKB powder is shown in Table 1. The moisture content of bean powder was $8.38 \%$. It has been found that bean powder contains a high amount of protein (26.25\%) and good amount of ash (3.27\%), but very low amount of fat $(2.40 \%)$. In addition, moisture and carbohydrate content of bean powder were $59.70 \%$ and $8.38 \%$, respectively. The results were similar to the study [15] and [16].

Table 1. Nutritional composition of RKB powder.

\begin{tabular}{cc}
\hline Physicochemical properties & Amount \% \\
Moisture content & $8.38 \pm 0.35^{\mathrm{b}}$ \\
Total ash content & $3.27 \pm 0.56^{\mathrm{a}}$ \\
Fat content & $2.4 \pm 0.19^{\mathrm{a}}$ \\
Protein content & $26.25 \pm 0.25^{\mathrm{c}}$ \\
Carbohydrate content & $59.7 \pm 1.35^{\mathrm{d}}$
\end{tabular}

*Values are mean \pm standard deviation of three replicates. 


\subsection{Functional Properties of RKB Powder}

The functional properties such as water absorption capacity, oil absorption capacity, swelling capacity and bulk density were analyzed shown in Table 2 . The water absorption capacity and oil holding capacity of bean powder was $4.97 \mathrm{~g} / \mathrm{g}$ and $4.50 \mathrm{~g} / \mathrm{g}$, respectively, which is similar to the study by [16]. The factors affecting water absorption capacity and oil holding capacity is protein content in food products [12], because protein has both hydrophilic and hydrophobic properties to interact with water and oil in food. The absorption or retention of water or oil of a flour has the ability to improve texture and mouth feel, and enhance the flavor [17]. The study indicated that swelling power of RKB is $9.6 \mathrm{~g} / \mathrm{g}$ that was in accordance with similar findings [16]. High swelling power indicates that ingredients can be added to enhance the quality of baked goods. However the bulk density of the bean powder was found as $0.74 \mathrm{~g} / \mathrm{ml}$, where [18] reported the bulk density of RKB as $0.41 \mathrm{~g} / \mathrm{ml}$.

\subsection{Proximate Analysis of Biscuits Fortified with RKB}

Nutritional compositions of biscuits partially replaced with bean flour at various levels $(0,10,20$, and 30$)$ are presented in Table 3 . The result shows that protein and ash content of control biscuits was $13.23 \%$ and $0.40 \%$, respectively. When the level of RKB powder in the biscuits increased from $10 \%$ to $30 \%$, the protein and ash content also increased significantly ( $\mathrm{p} \leq 0.05$ ) ranged from $15.31 \%$ to $20.80 \%$ and from $0.80 \%$ to $1.90 \%$, respectively. The similar trend was found in a study conducted by [19]. On the other hand, with increasing the level of RKB

Table 2. Functional properties of RKB powder.

\begin{tabular}{cc}
\hline Property & RKB powder \\
\hline Water absorption capacity $(\mathrm{g} / \mathrm{g})$ & $4.97 \pm 0.58$ \\
Oil holding capacity $(\mathrm{g} / \mathrm{g})$ & $4.50 \pm 1.34$ \\
Swelling capacity $(\mathrm{g} / \mathrm{g})$ & $9.60 \pm 0.20$ \\
Bulk density $(\mathrm{g} / \mathrm{ml})$ & $0.74 \pm 0.07$ \\
\hline
\end{tabular}

${ }^{*}$ Values are mean \pm standard deviation of three replicates.

Table 3. Nutritional compositions of biscuits fortified with various level of RKB.

\begin{tabular}{|c|c|c|c|c|}
\hline Parameters & Control & $10 \% \mathrm{RKB}$ & $20 \% \mathrm{RKB}$ & $30 \% \mathrm{RKB}$ \\
\hline Moisture (\%) & $2.06 \pm 0.89^{\mathrm{a}}$ & $2.15 \pm 0.15^{\mathrm{a}}$ & $2.29 \pm 0.21^{\mathrm{a}}$ & $2.61 \pm 1.23^{\mathrm{a}}$ \\
\hline Total Ash (\%) & $0.40 \pm 0.06^{\mathrm{a}}$ & $0.80 \pm 0.08^{\mathrm{ab}}$ & $1.03 \pm 0.27^{\mathrm{b}}$ & $1.90 \pm 0.33^{c}$ \\
\hline Protein (\%) & $13.23 \pm 0.08^{\mathrm{a}}$ & $15.31 \pm 0.35^{\mathrm{b}}$ & $17.93 \pm 0.89^{c}$ & $20.80 \pm 0.20^{\mathrm{d}}$ \\
\hline Fat (\%) & $12.23 \pm 0.08^{c}$ & $11.71 \pm 0.35^{\mathrm{bc}}$ & $11.26 \pm 0.89^{\mathrm{ab}}$ & $10.80 \pm 0.20^{\mathrm{a}}$ \\
\hline Carbohydrate (\%) & $72.08 \pm 0.37^{\mathrm{c}}$ & $70.03 \pm 0.79^{c}$ & $67.49 \pm 1.53^{\mathrm{b}}$ & $63.89 \pm 1.02^{\mathrm{a}}$ \\
\hline $\begin{array}{l}\text { Total gross energy } \\
(\mathrm{kj} / 100 \mathrm{gm})\end{array}$ & $1628.92 \pm 15.87^{c}$ & $1620.74 \pm 3.84^{c}$ & $1614.56 \pm 8.02^{b}$ & $1594.68 \pm 5.51^{\mathrm{a}}$ \\
\hline
\end{tabular}

*Values are mean \pm standard deviation of three replicates. 
from $0 \%$ to $30 \%$, fat content did not change notably ranged from $12.23 \%$ $10.80 \%$, but carbohydrate contents reduced extensively from $72 \%-63.89 \%$, almost similar to the study by [19]. As a result, the energy value with the addition of kidney bean powder decreased significantly from 1620.73 to $1594.68 \mathrm{~kJ} / 100 \mathrm{~g}$, while control biscuit possessed the highest energy $(1628.92 \mathrm{~kJ} / 100 \mathrm{~g})$. However, the moisture content did not show any significant changes with increasing the level of fortification.

\subsection{Total Phenolic Content}

The results from Table 4 showed that total phenolic content of RKB was found $14.14 \mathrm{mg} \mathrm{GAE} / \mathrm{g}$ which is in the range of TPC (5.87 - $14.14 \mathrm{mg} \mathrm{GAE} / \mathrm{g})$ for the common beans reported by ([20] [21]). But another study [22] showed that the TPC of twelve Italian cultivars of $P$. vulgaris ranged from 1.17 - $4.40 \mathrm{mg}$ GAE/g. It probably varied because of the extraction and determination method of phenolic contents and it also could be the regional variation of the beans species. The TPC of wheat flour biscuit was found as $10.31 \mathrm{mg} \mathrm{GAE} / \mathrm{g}$, which was similar to the study conducted by [23] who found that TPC of control was $11.37 \mathrm{mg}$ $\mathrm{GAE} / \mathrm{g}$. Increasing the level of RKB powder from $10 \%-30 \%$ also increased the TPC from 11.19 - $12.50 \mathrm{mg} \mathrm{GAE} / \mathrm{g}$, similar trend was found in the study reported by [24], where prickly pear peel and potato peel powder was incorporated with wheat flour.

\subsection{Antioxidant Activity}

Figure 1 shows DPPH-radical scavenging activity (DRSA) of raw RKB powder, control, 10\%, 20\%, 30\% RKB fortified biscuits and a standard ascorbic acid at various concentration (from $0.016-10 \mathrm{mg} / \mathrm{ml}$ ). The results reveal that ascorbic acid showed highest antioxidant activity ranged from $89.37 \%-93.63 \%$ at various concentration ranged from $0.016-10 \mathrm{mg} / \mathrm{ml}$, followed by raw RKB, control, $10 \%, 20 \%$, and $30 \%$ supplementation. Raw bean powder showed significantly ( $\mathrm{p}$ $<0.05)$ higher antioxidant activity than other fortified biscuits, which was reflected in the $\mathrm{IC}_{50}$ value of $0.0210 \mathrm{mg} / \mathrm{ml}$ (Table 5). Another study by [3] found that at $0.4 \mathrm{mg} / \mathrm{ml}$ concentration DPH-1 antioxidant activity of RKB powder was

Table 4. Total phenolic content of raw RKB powder and different level of fortified biscuits.

\begin{tabular}{cc}
\hline Sample & TPC $(\mathrm{mg} \mathrm{GAE} / \mathrm{g})$ \\
\hline Raw RKB & $14.15 \pm 0.27^{\mathrm{a}}$ \\
Control & $10.31 \pm 0.34^{\mathrm{b}}$ \\
$10 \%$ RKB & $11.19 \pm 0.63^{\mathrm{c}}$ \\
$20 \%$ RKB & $11.90 \pm 0.24^{\mathrm{d}}$ \\
$30 \%$ RKB & $12.50 \pm 0.64^{\mathrm{e}}$ \\
\hline
\end{tabular}

${ }^{*}$ Values are mean \pm standard deviation. Values in column with different letter superscripts are significantly different at $\mathrm{p} \leq 0.05$. 


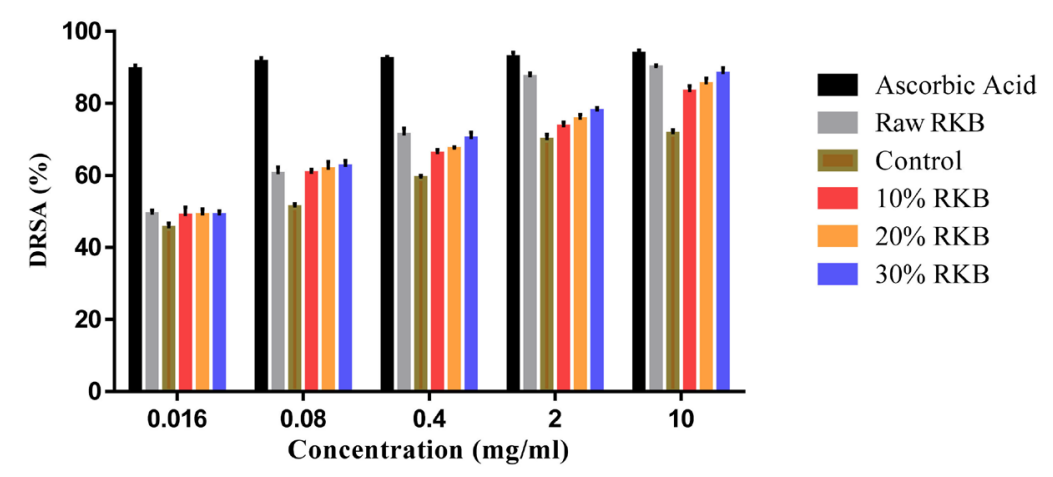

Figure 1. Antioxidant activity of RKB and fortified biscuits.

Table 5. $\mathrm{IC}_{50}$ values of raw RKB, control, $10 \%, 20 \%$ and $30 \%$ RKB fortified biscuits.

\begin{tabular}{cc}
\hline Sample & $\mathrm{IC}_{50}$ value $(\mathrm{mg} / \mathrm{ml})$ \\
\hline Raw RKB & $0.0210 \pm 0.0031^{\mathrm{a}}$ \\
Control & $0.0228 \pm 0.0063^{\mathrm{ab}}$ \\
$10 \%$ RKB & $0.0227 \pm 0.0015^{\mathrm{abc}}$ \\
$20 \%$ RKB & $0.0221 \pm 0.0045^{\mathrm{bc}}$ \\
$30 \%$ RKB & $0.0215 \pm 0.0054^{\mathrm{c}}$ \\
\hline
\end{tabular}

${ }^{*}$ Values are mean \pm standard deviation. Values in column with different letter superscripts are significantly different at $\mathrm{p} \leq 0.05$.

$81.41 \%$, where this study shows slightly different capacity $(71.11 \%)$ because of extraction and determination method. Compared to the ascorbic acid, the samples showed significantly lower $(\mathrm{p}<0.05)$ DPPH-radical scavenging activity. Loss of antioxidant activity was observed during baking process. Polyphenol compounds are liable for showing antioxidant activity [25]. So for leaching out of polyphenols, antioxidant activity might be decreased significantly $(\mathrm{p}<0.05)$. Antioxidant activity increased with the increasing concentration of bean powder, similar study was found in another study [26] for cocoa powder incorporation in biscuits.

\subsection{Effects of RKB Powder on Physical Properties of Biscuits}

The cakes were evaluated for their diameter, thickness, weight and spread ratio after and before the incorporation of RKB powder shown in Table 6. The control cake contained the highest spread ratio (8.92) and the spread ratio decreased from 8.25 - 7.86 with the increase of fortification level from $10 \%-30 \%$. The decrease in spread ratio was observed for the dilution of gluten and less availability of water for gluten hydration reported by [27]. The decrease in the spread ratio was due to the decrease in the diameter (from $5.21-5.20 \mathrm{~cm}$ ) and increase in the thickness of the cake (from $0.53-0.57 \mathrm{~cm}$ ). Similar results had been reported for biscuits with cocoa powder [26]. On the other hand, the weight of the RKB fortified biscuits increased with the fortification ranged from $4.25-6.03 \mathrm{~g}$. 


\subsection{Sensory Evaluation of Biscuits Fortified with Different Level of RKB Powder}

The biscuits added with $10 \%, 20 \%$ and $30 \%$ bean powder were subjected to sensory analysis shown in Figure 2. Control biscuits got satisfactory score in color (6.27), aroma (6.45) taste (6.27) and overall acceptability (6.18), but $10 \%$ supplementation superseded the control in color by 6.64 , aroma by 6.47 , taste by 6.89 , and overall acceptability by 6.34 . The formulation with $20 \%$ and $30 \%$ kidney bean did not get satisfactory score in sensory evaluation. Color and aroma depends on reducing sugar and amino acids (protein content). Reducing sugar and amino acids are responsible for the Malliard reaction that gives desirable brown color and flavor of foods [28].

\section{Conclusion}

This research was carried out to investigate how the physicochemical properties, polyphenol content and antioxidant activity of dark RKB powder change the wheat flour biscuits at various level of fortification. The physicochemical properties varied vividly with the addition of RKB flour. Protein and ash content of biscuits increased significantly with decreasing carbohydrate and energy level at higher level of fortification, while fat and moisture content changed very little. Considering its high protein and low energy level, wheat-red kidney bean biscuits can be cheap sources of nutritious food. Total phenolic content and antioxidant activity of RKB fortified biscuits were increased significantly $(\mathrm{p}<0.05)$

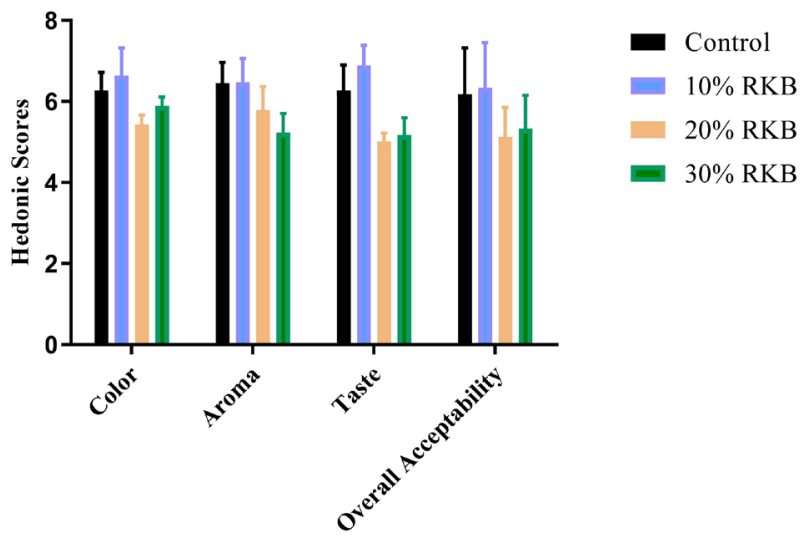

Figure 2. Mean sensory scores of RKB supplemented biscuits.

Table 6. Physical properties of RKB fortified biscuits at four different levels.

\begin{tabular}{ccccc}
\hline \multirow{2}{*}{ Parameter } & Control & \multicolumn{3}{c}{ Different level of RKB fortified biscuits } \\
\cline { 3 - 5 } & & $10 \%$ RKB & $20 \%$ RKB & $30 \%$ RKB \\
\hline Diameter $(\mathrm{cm})$ & $5.56 \pm 0.01$ & $5.21 \pm 0.06$ & $5.18 \pm 0.03$ & $5.20 \pm 0.18$ \\
Thickness $(\mathrm{cm})$ & $0.55 \pm 0.15$ & $0.53 \pm 0.04$ & $0.55 \pm 0.07$ & $0.57 \pm 0.02$ \\
Weight $(\mathrm{g})$ & $4.25 \pm 0.08$ & $4.58 \pm 0.59$ & $5.87 \pm 0.60$ & $6.03 \pm 0.38$ \\
Spread ratio & $8.92 \pm 0.21$ & $8.25 \pm 0.75$ & $8.19 \pm 0.62$ & $7.86 \pm 0.12$ \\
\hline
\end{tabular}


with increasing the level of fortification. However, 10\% RKB fortified biscuits were found satisfactory to the consumers in overall perspective and acceptability test. Therefore, to increase the nutritional value and bioactive compounds of biscuits with $10 \%$ RKB fortification is apposite with great consumer acceptance.

\section{Acknowledgements}

The authors are grateful to the Department of Food Engineering and Tea Technology, Shahjalal University of Science and Technology, for the encouragement and providing facilities to carry out the present study.

\section{Conflicts of Interest}

The authors declare no conflicts of interest regarding the publication of this paper.

\section{References}

[1] Rahman, M.M., Bakr, M.A., Mia, M.F. and Idris, M.S. (2000) Legumes in Bangladesh. In: Legumes in Rice and Wheat Cropping Systems of the Indo-Gangetic Plain Constraints and Opportunities, International Crops Research Institute for the Semi-Arid Tropics, Patancheru, 5-34.

[2] Olanipekun, O.T., Omenna, E.C., Olapade, O.A., Suleiman, P. and Omodara, O.G. (2015) Effect of Boiling and Roasting on the Nutrient Composition of Kidney Beans Seed Flour. Sky Journal of Food Science, 4, 24-29.

[3] Roy, M., Sarker, A., Azad, M.A.K., Shaheb, M.R. and Hoque, M.M. (2020) Evaluation of Antioxidant and Antimicrobial Properties of Dark Red Kidney Bean (Phaseolus vulgaris) Protein Hydrolysates. Journal of Food Measurement and Characterization, 14, 303-313. https://doi.org/10.1007/s11694-019-00292-4

[4] Masuda, T. and Nisbett, R.E. (2003) Culture and Point of View. Proceedings of the National Academy of Sciences of the United States of America, 100, 11163-11175. https://doi.org/10.1073/pnas.1934527100

[5] Xu, B.J. and Chang, S.K.C. (2008) Total Phenolic Content and Antioxidant Properties of Eclipse Black Beans (Phaseolus vulgaris L.) as Affected by Processing Methods. Journal of Food Science, 73, 19-27. https://doi.org/10.1111/j.1750-3841.2007.00625.x

[6] AOAC (2002) Official Method of Analysis of AOAC International. 17th Edition, AOAC, Washington DC.

[7] Ravichandran, R. and Parthiban, R. (2000) Lipid Occurrence, Distribution and Degradation to Flavor Volatiles during Tea Processing. Food Chemistry, 68, 7-13. https://doi.org/10.1016/S0308-8146(99)00143-0

[8] AACC (2000) Approved Methods of the American Association of Cereal Chemists. 10th Edition, Am. Assoc. Cereal Chem., Inc., St. Paul.

[9] Rui, X., Boye, J.I., Ribereau, S., Simpson, B.K. and Prasher, S.O. (2011) Comparative Study of the Composition and Thermal Properties of Protein Isolates Prepared from Nine Phaseolus vulgaris Legume Varieties. Food Research International, 44, 2497. https://doi.org/10.1016/j.foodres.2011.01.008

[10] Pranoto, Y., Rahmayuni, H. and Rakshit, S.K. (2014) Physicochemical Properties of Heat Moisture Treated Sweet Potato Starches of Selected Indonesian Varieties. Indonesian Food Research Journal, 21, 2031-2038. 
[11] Brishti, F.H., Zarei, M., Muhammad, S.K.S., Ismail-Futry, M.R. and Shukri, R. (2017) Evaluation of the Functional Properties of Mung Bean Protein Isolate for Development of Textured Vegetable Protein. International Food Research Journal, 24, 1595-1605.

[12] Butt, M.S. and Batool, R. (2010) Nutritional and Functional Properties of Some Promising Legumes Protein Isolates. Pakistan Journal of Nutrition, 9, 373-379. https://doi.org/10.3923/pjn.2010.373.379

[13] Velioglu, Y.S., Mazza, G., Gao, L. and Oomah, B.D. (1998) Antioxidant Activity and Total Phenolics in Selected Fruits, Vegetables, and Grain Products. Journal of Agricultural and Food Chemistry, 46, 4113. https://doi.org/10.1021/jf9801973

[14] Yen, G.C. and Chen, H.Y. (1995) Antioxidant Activity Various Tea Extracts in Relation to Their Antimutagenicity. Journal of Agricultural and Food Chemistry, 43, 27. https://doi.org/10.1021/jf00049a007

[15] Hayat, I., Ahmad, A., Ahmed, A., Shakil, S. and Gulfraz, M. (2014) Exporing the Potential of Red Kidney Bean (Phaseolus vulgaris L.) to Develop Protein Based Product for Food Applications. The Journal of Animal \& Plant Science, 24, 860-868.

[16] Ratnawati, L., Desnilasari, D., Surahman, D.N. and Kumalasari, R. (2019) Evaluation of Physico Chemical, Functional and Pasting Properties of Soybean, Mung Bean and Red Kidney Bean Flour as Ingredient in Biscuit. IOP Conference Series. Earth and Environmental Science, 251, 12-26. https://doi.org/10.1088/1755-1315/251/1/012026

[17] Kisambira, A., Muyonga, J.H., Byaruhanga, Y.B., Tukamuhabwa, P., Tumwegamire, S. and Gruneberg, W.J. (2015) Composition and Functional Properties of Yam Bean (Pachyrhizus spp.) Seed Flour. Food and Nutrition Sciences, 6, 736-746. https://doi.org/10.4236/fns.2015.68076

[18] Pangastuti, H.A., Affandi, D.R. and Ishartani, D. (2013) Characterization of the Physical and Chemical Properties of Flour Kidney Beans (Phaseolus vulgaris L.) with Some Preliminary Treatments. Journals Food Technology, 21, 20-29.

[19] Inyang, U.E., Daniel, E.A. and Bello, F.A. (2018) Production and Quality Evaluation of Functional Biscuits from Whole Wheat Flour Supplemented with Acha (Fonio) and Kidney Bean Flours. Asian Journal of Agriculture and Food Sciences, 6, 193-201. https://doi.org/10.24203/ajafs.v6i6.5573

[20] Akond, A.S.M.G.M., Berthold, J., Gates, L., Peters, K., Delong, H. and Hossain, K. (2011) Anthocyanin, Total Polyphenols and Antioxidant Activity of Common Bean. American Journal of Food Technology, 6, 385-394.

https://doi.org/10.3923/ajft.2011.385.394

[21] Wu, X., Beecher, G.R., Holden, J.M., Haytowitz, D.B., Gebhardt, S.E. and Prior, R.L. (2006) Concentrations of Anthocyanins in Common Foods in the United States and Estimation of Normal Consumption. Journal of Agricultural and Food Chemistry, 54, 4069-4075. https://doi.org/10.1021/jf0603001

[22] Heimler, D., Vignolini, P., Dini, M.G. and Romani, A. (2005) Rapid Tests to Assess the Antioxidant Activity of Phaseolus vulgaris L. Dry Beans Journal of Agricultural and Food Chemistry, 53, 3053-3056. https://doi.org/10.1021/jf049001r

[23] Mahloko, L.M., Silungwe, H., Mashau, M.E. and Kgatla, T.E. (2019) Bioactive Compounds, Antioxidant Activity and Physical Characteristics of Wheat-Prickly Pear and Banana Biscuits. Heliyon, 5, e02479. https://doi.org/10.1016/j.heliyon.2019.e02479

[24] Elhassaneen, Y., Ragab, R. and Mashal, R. (2016) Improvement of Bioactive Compounds Content and Antioxidant Properties in Crackers with the Incorporation of 
Prickly Pear and Potato Peels Powder. International Journal of Nutrition and Food Sciences, 5, 55-61. https://doi.org/10.11648/j.ijnfs.20160501.18

[25] Ismail, A., Marjan, Z.M. and Foong, C.W. (2004) Total Antioxidant Activity and Phenolic Content in Selected Vegetables. Food Chemistry, 87, 581-586.

https://doi.org/10.1016/j.foodchem.2004.01.010

[26] Ajibola, C.F., Oyerinde, V.O. and Adeniyan, O.S. (2015) Physicochemical and Antioxidant Properties of Whole-Wheat Biscuits Incorporated with Moringa oleifera Leaves and Cocoa Powder. Journal of Scientific Research \& Reports, 7, 195-206. https://doi.org/10.9734/JSRR/2015/18070

[27] Sharma, P., Velu, V., Indrani, D. and Singh, R.P. (2013) Effect of Dried Guduchi (Tinospora cordifolia) Leaf Powder on Rheological, Organoleptic and Nutritional Characteristics of Cookies. Food Research International, 50, 704-709. https://doi.org/10.1016/j.foodres.2012.03.002

[28] Maillard, L.C. (1912) Formation of Melanoidins in a Methodical Way. Comptes Rendus, 154, 66-68. https://doi.org/10.3917/rfsp.661.0154 